\title{
EUTHANASIA: THEORETICAL AND LEGAL PRINCIPLES
}

\section{Hromovchuk M. V.}

\section{INTRODUCTION}

The term "euthanasia" introduced the English philosopher F. Bacon to indicate mild and painless death. In modern science, euthanasia is understood as deliberate acceleration of mild death terminally ill individual with the aim of ending his suffering and torment; in other words, euthanasia - an action or inaction aimed at putting an end to the life of a terminally ill person, meeting his own desire and performed by a doctor or other disinterested person.

The relevance of the study of the problem of euthanasia due to a number of circumstances: contradictions between the previously used criteria for determining a person's death and its new scientific understanding caused by the successes of modern resuscitation, between the cultural and religious traditions of society considering euthanasia like murder or suicide, and an increasingly recognized human right in certain cases do not continue your suffering; imperfection legislation (on the one hand, a ban on euthanasia without dividing it into active and passive is expressed in Article 45 of the Law "Fundamentals of Legislation on protection of the health of citizens of the Russian Federation”, on the other, according to Art. 33 of the same Fundamentals, the patient can refuse any medical action); methodological lack of development of this issue (in the traditional there is no category of incurable medicine sick"; the main goal of medicine is to maintain health, cure diseases, while in patients the category in question this goal cannot be implemented), etc.

The results of the study showed that in the domestic public discourse is absent even relative consensus on the issue of the legitimacy of euthanasia. So, according to a survey conducted by the POF, 32\% supported the idea of euthanasia and exactly the same amount against her. More than those who found it difficult to answer this question (36\%). To the question, could respondents request euthanasia under certain circumstances, $27 \%$ replied positively, 35\% - negatively, and 38\% found it difficult to answer.

The religious view of euthanasia is more categorical than public opinion, but also ambiguous. Christianity mainly advocates against euthanasia. According to the Islamic Code medical ethics, “... the requirement to kill in order to reduce suffering, rejects”, but the Code does not consider it necessary to artificially maintain life in a body with a dying mind. In 2005 The Knesset of Israel passed a law that allows terminally ill patients to demand that doctors stop their torment. Judaism stands for not to prolong life artificially: salvation 
from pain is not in itself an excuse for killing, but doctors are not required make the patient suffer even more, artificially prolonging his life.

Thus, in a religious context if we can talk about the possibility of euthanasia, then only about the passive - in the form of discontinuation of maintenance therapy. Active euthanasia involves actions that lead to the soonest death. The following active forms are distinguished euthanasia: 1) death from compassion; 2) voluntary active euthanasia; 3) suicide with the help of a doctor. In the 2nd and 3rd cases, consent (or even requirement) is decisive the most ill. In the 2nd case the doctor at the request the patient makes him a lethal injection, and in the $3^{\text {rd }}$ the doctor passes into the hands of the patient a means that allows him to commit suicide. For example passive euthanasia is the doctor's self-elimination from treatment of the patient and refusal of the latter from continuation of treatment. A form of euthanasia is also the case when the patient is discharged hopelessly ill, and the situation when the patient is doomed to die because of lack of medication or equipment.

The question of euthanasia arise in the situation of irreversible loss of functions of the brain, when a person is completely dependent on the apparatus of artificial support for life. In addition to active and passive euthanasia, voluntary, involuntary and involuntary euthanasia are distinguished. Voluntary euthanasia is carried out at the request of the patient or with the previously given consent, involuntary - without the consent of the patient, as a rule, who is unconscious; it is made by decision of relatives, guardians, etc. An example of involuntary euthanasia is the termination of life of "extra" people. This is the official name the eugenic program of the German National Socialists for sterilization, and later on the physical destruction of people with mental disorders who are mentally retarded and hereditarily burdened. Subsequently in a circle the persons who were destroyed were disabled persons with disabilities, as well as patients over 5 years.

Currently in Germany the concept of "euthanasia" is rarely used because it is discredited murders committed during Nazism. Individual authors distinguish between direct and indirect euthanasia, which reflects the motivation of professional decisions of the doctor. Direct euthanasia - when the doctor intends to reduce patient's life; indirect - when the death of the patient is accelerated as an indirect (by-effect) consequence of the doctor's actions toward another goal. As a rule, we are talking about increasing doses of painkillers (opioids), resulting in a shorter life of the patient. The modern understanding of euthanasia includes a whole complex of interrelated aspects, among which usually distinguish biological-medical, moral-moral, legal, religious. The biological-medical aspect of the problem lies primarily in the establishment categories of patients in relation to which the possibility of application may be considered euthanasia. At the center of the ethical aspect is question: Is it morally and merciful at all to interrupt the life of even a severely suffering person? Shouldn't such action be considered ordinary 
murder? Does the idea of euthanasia itself not contradict the very essence of the medical profession, which is designed to preserve rather than lose life? Legal the problem is the need to develop a legal procedure for euthanasia in the event that this act is authorized by law. The religious aspect, which is essential for believing patients, is characterized by a solution that is unambiguous for all faiths: life, however difficult, is given to a person above, which deprives him of his right to forcibly interrupt him.

\section{Euthanasia as international category}

In international law during the last for years, the issue of euthanasia remains highly relevant, primarily as a result of increased interest in euthanasia in the legal doctrine and practice of some states. How often it is it is the source of a legal model of behavior in international human rights regulation is national law. Today this one the fact is recognized by all international human rights bodies, and therefore more fully analysis should also refer to the national laws of individual states. Among the international legal acts that regulate the right to life and thus are involuntarily relevant euthanasia include, in particular, the Universal Declaration of Human Rights of 10 December 1948, European Convention for the Protection of Human Rights human rights and fundamental freedoms of 4 November 1950 (as amended), certain international documents of medical associations, and namely the 1997 Council of Europe Convention on the Protection of Rights and human dignity in relation to the application of biology and Medicine: Convention on Human Rights and Biomedicine, "as well other legal acts. However, the issue of euthanasia has not been settled directly in international law, though in 1987. The 39th World Medical Assembly in Madrid has adopted the Declaration of Euthanasia. The text of the document says: "Euthanasia, as an act deliberately depriving a patient of his life, even at the request of the patient himself or at the request of his relatives, is not ethical. Not eliminates the need to respect the doctor's desire the patient does not interfere with the course of the natural process of dying in the terminal phase of the disease".

Today, euthanasia is used in many countries, whether or not permitted by law. There are a number of countries where euthanasia is legalized and widely used. The pioneer in the legislative consolidation of the right to euthanasia is the state of California in the United States, where in 1977 was adopted Law on the Human Right to Death. Following California's example, euthanasia was allowed in Oregon, subject to a number of prerequisites and careful controls. Suicide at medical assistance is not specifically prosecuted or punished under the laws of the states of North Carolina, Utah, Wyoming. Interesting is the practice of Indiana: on its territory operates a so-called life covenant in which the patient officially confirms his will to ensure that his life did not continue artificially by in certain circumstances. 
International law should specifically regulate euthanasia, they must specify who to whom the way in which circumstances and on what grounds can exercise or promote the human right to "easy death". International law, as well as the national law of the states, faces problems that are impossible to properly inadequate assessment of what is happening, patients who are in a very serious condition. Given the above factors, international practice, and the fact that, at the present stage, the development of medicine allows actively combat pathological conditions that have not yet been treated it has been quite problematic for a long time, I think it is necessary to establish in international law the rules that would regulate the issue euthanasia. In this case, the right to euthanasia is regulated, understand the enshrining in international legal acts of prohibition "Murder at the request of the patient", but also predicting the list conditions and features of euthanasia in some exceptional cases.

The Council of Europe Committee on Bioethics has conducted research on euthanasia in the States Europe and presented its results in the document "Questions and Answers on Euthanasia" by January 20, 2003. In countries that have already legalized euthanasia, there are not even clear criteria definition of this concept, not to mention on the delineation of euthanasia by species. The question of whether who is eligible for euthanasia. Sometimes it is doctor, application approved by the patient, but it's basically the third, uninterested person. There are also differences about this one who has the right to ask for euthanasia. The age of the person, their mental state, legal capacity and diagnosis. It is equally important and the question of the validity of the request for euthanasia in writing or orally.

Decriminalization of euthanasia, as stated by the Parliamentary Assembly of the Council of Europe (PACE) in a document dated 10.09.2003, will allow to control this process and limit it with clear the scope of the law. Because only controlled procedures and clear rules of application euthanasia will put an end to an arbitrary system, existing in many European countries.

On January 25, 2012, the PACE adopted a resolution (1859) "Protecting the Rights and Dignity of the Person of taking into account the previously expressed wishes of the patient", which stated that "euthanasia, as premeditated murder, by action or the inaction of an incapacitated person in his or her best interests should be prohibited." This resolution seeks to determine principles to be applied in Europe, such as the "covenant for life" or "early guidance". Previously PACE in the recommendation (1418) "On the Protection of Human Rights and Dignity terminally ill and dying" insisted on the "prohibition of intentional deprivation life of terminally ill or dying person.” PACE and Council of Europe member states continue to condemn euthanasia and assisted suicide. 


\section{Euthanasia as category of law science}

For many years, the issue of euthanasia has got a mixed reaction in society. The term "euthanasia" was introduced in XVI century by an English philosopher F. Bacon who discussing the purpose and tasks of medicine in his paper "On the Dignity and Advancement of Learning” focused on the issue of incurable diseases ${ }^{1}$. Furthermore, M.Koval, referring to H. Tereshkevych, marks that originally, in medicine, the term "euthanasia" meant loving help to a person who is dying, a desire to reduce his/her patience and fear. Subsequently, the term got a radically different meaning than F. Bacon's interpretation - the care of the terminally ill persons or people who are knocking on heaven's door ${ }^{2}$.

Nowadays, "euthanasia" means completely negative and opposite concept than F. Bacon proposed. For this very reason, one can observe numerous disputes between medical workers, lawyers, psychologists, as well as religious leaders. Thus, according to some modern scholars, an attitude to death serves as a standard, indicator and characteristic of civilization, but when one looks at modern society, one observes that it represses death from the collective consciousness; the society acts as if nobody dies, and the death of the individual leaves no marks in the social structure. Moreover, in the most developed and democratic countries of the world, the death of a person is perceived as a matter of doctors and business people who deal with funeral service ${ }^{3}$.

Euthanasia, as a medical procedure, is applied to patients whose biological death is inevitable and who feel severe physical sufferings while dying. There is another category of patients - persons who are in a persistent vegetative state. At the same time, the problem concerned has the other side. Many scholars are a bit apprehensive that a formal solution to this problem may become a kind of brake for the search for more effective means of diagnosis and treatment of acute patients. It is beyond the argument that a physician shouldn't bow to a patient wishing to use this procedure. It is permissible only in exceptional cases, that is, when there are no chances for a cure and protracting a person's life, one foredooms him/her to sufferings.

In the context of the above, we fully share M. Koval's statement that "at the same time, there cannot be two true or objective laws in the world. The truth does not need confirmation of another truth as the truth is absolute. The voice of nature originating from the Law of the Lord says

\footnotetext{
${ }^{1}$ Коваль М.І. Контрміра евтаназії - паліативне лікування. Вісник соиіальної гігієни та організаиії охорони здоров'я Украӥни. 2015. № 3 (65). С. 55.

${ }_{2}$ Терешкевич Г. Т. Основи біоетики та біобезпеки : підручник. Тернопіль : ТДМУ, 2014. $400 \mathrm{c}$.

${ }^{3}$ Коротких К. С. Эвтаназия как философско-правовая проблема. Вісник Національного університету «Юридична академія Украӥни імені Ярослава Мудрого». 2012. № 4 (14). C. 141-149.
} 
"You shall not murder" (Exodus 20:13). However, the scholar says that along with the law, there is anti-law which always seeks to falsify its truth and denies the truth of the law. There is the same situation with euthanasia. The modern stage of reforming healthcare in Ukraine involves extending the bioethical knowledge of a young physician or pharmacist to form his/her moral, ethical and deontological mentality to evaluate events and phenomena from the standpoint of absolute, eternal and unchanging universal humanistic values” ${ }^{4}$.

\section{Euthanasia and bioethics: correlation issues}

A terminally ill patient should be treated differently than other patients. However, there are no any legal documents which regulate a physician's actions towards a dying patient, and they can't be. Most scholars tend to think that above all, one should follow the ethical principles enshrined in the Hippocratic Oath as well as the recommendations of the World Medical Association Declaration of Helsinki ${ }^{5}$.

However, when analyzing the issues of medical and legal aspects of euthanasia, it is also essential to pay attention to the category "bioethics". Modern international documents on medical ethics (bioethics) developed by the World Medical Association, the Council of Europe, the World Health Organization, UNESCO, World Psychiatric Association etc. include more than one hundreds of pages. Thus, let's consider extracts from the documents of the World Psychiatric Association:

- "Joining medical community: I solemnly pledge myself to consecrate my life to the service of humanity... I will maintain the utmost respect for human life from the time of conception... I will respect the secrets that are confided in me, even after the patient has died..." (WMA Declaration of Geneva, 1948, 1968, 1983, 1994);

- "A physician shall be dedicated to providing competent medical service in full professional and moral independence, with compassion and respect for human dignity. A physician shall not allow his/her judgment to be influenced by personal profit or unfair discrimination" (International Code of Medical Ethics, 1949, 1968, 1983);

- "The patient has the right to accept or refuse treatment after receiving adequate information. The patient is entitled to humane terminal care and to be provided with all available assistance in making dying as dignified and comfortable as possible" (WMA Declaration of Lisbon on the Rights of the Patient, 1981, 1955);

${ }^{4}$ Коваль М.І. Контрміра евтаназії - паліативне лікування. Вісник соціальної гігієни та організаиії охорони здоров'я України. 2015. № 3 (65). С. 54.

${ }^{5}$ URL: https://zakon.rada.gov.ua/laws/show/990_005. 
- "The physician may relieve suffering of a terminally ill patient by withholding treatment with the consent of the patient or his immediate family if unable to express his will” (Declaration of Venice on Terminal Illness, 1983);

- "Euthanasia, that is the act of deliberately ending the life of a patient, even at the patient's own request or at the request of close relatives, is unethical. This does not prevent the physician from respecting the desire of a patient to allow the natural process of death to follow its course in the terminal phase of sickness" (WMA Resolution on Euthanasia, 1987);

- "The care of terminally ill patients with severe chronic pain should provide treatment that permits these patients to close their lives with dignity and purpose. It is incumbent on the physician and on all others who care for the dying patient with severe chronic pain to understand... the needs of the patient, family and friends” (WMA Statement on the Care of Patients with Severe Chronic Pain in Terminal Illness, 1990);

- "Physicians played a prominent role in the elderly abuse movement by defining and publicizing the problem...Once high-risk individuals and families have been identified, physicians can participate in the primary prevention of maltreatment by making referrals to appropriate community and social service centres” (WMA Declaration of Hong Kong on the Abuse of the Elderly, 1989, 1990);

- "Patients with AIDS and those who test positively for the antibody to the AIDS virus must be provided with appropriate medical care... Physicians have a long and honored tradition of tending to patients afflicted with infectious diseases with compassion and courage. That tradition must be continued throughout the AIDS epidemic (WMA Statement on the Professional Responsibility of Physicians in Treating Aids Patients, 1988; WMA Interim Statement on AIDS);

- "Physicians treating hunger strikers are faced with the following conflicting values: ... moral obligation on every human being to respect the sanctity of life ... physicians should respect individuals' autonomy... Ethical conduct: ... any treating provided to the patient should be approved by him...Artificial feeding: when the hunger striker has become confused and is therefore unable to make an unimpaired decision or has lapsed into a coma, the physician shall be free to make the decision for his patient as to further treatment which he considers to be in the best interest of that patient, always taking into account the decision he has arrived at during his preceding care of the patient during his hunger strike" (WMA Declaration on Hunger Strikers, 1992);

- “...To be sure, the individuals involved were seriously ill, perhaps even terminally ill, and were wracked with pain... Furthermore, the individuals were apparently competent and made their own decision to commit suicide... In other instances the physician has provided medication to the individual with information as to the amount of dosage that would be lethal... 
Physician-assisted suicide, like euthanasia, is unethical and must be condemned by the medical profession" (WMA Statement on PhysicianAssisted Suicide, 1992);

- "It is unethical for physicians to participate in capital punishment that is not a problem for physicians to pronounce death" (WMA Resolution on Physician Participation in Capital Punishment, 1981).

However, despite a significant number of regulations related to euthanasia, studies conducted in the US and the Netherlands indicate that only a third of requests on life termination using euthanasia are caused by insufferable pain of a patient ${ }^{6}$.

A scholar A. Panishchov ${ }^{7}$ provides several examples where euthanasia supporters under the slogan of assistance in its implementation killed healthy people. Thus, in the USA, in 1956 Jack Kevorkian, who is called "Doctor Death", substantiated the expediency of euthanasia introduction. In 1989, he constructed a so-called "suicide machine" which assisted the death of more than 120 persons. In December 2000, a group of physicians stated that J. Kevorkian used it in the cases not related to terminal illnesses. According to this conclusion, $75 \%$ of patients treated by Death Doctor with mild death were patients who were not incurable, and 5\% of them were healthy.

Another example is H. Shipman, who was a life-sentence prisoner for the murder of 15 patients. During the investigation, it was proved that the physician committed the first murder in 1984. When he visited an older woman suffering from joint pain, G. Shipman offered to give her an injection of an analgetic, the woman agreed, and the doctor administered her 30 milligrams of diamorphine (the medical term for heroin). Then he was observing as the victim was dying.

In January 2001, the UK Department of Health released a report suggesting that Mr Shipman committed about 300 murders of patients during his many years of practice in Hyde, Manchester. Before leaving the home of a murdered patient, he usually took a little knickknack as a keepsake and always sent a sympathy card to relatives. $\mathrm{H}$. Shipman was suspected when he had given Hyde's former mayor an injection and then fabricated a will according to which a family physician inherited the wealth amounting $£ 350,000$.

It should be emphasized that in Europe, active euthanasia is permitted in three countries: the Netherlands since 2002, Belgium since 2002, Luxembourg since 2009 and the Swiss canton of Zürich since $2011^{8}$.

${ }^{6}$ URL: Kebuladze B. Termination of Life on Request and Assisted Suicide European Scientific Journal December 2016 /SPECIAL/ edition ISSN: 1857-7881 (Print) e - ISSN 1857-7431. S. $424(421-425)$

7 Панищев А.Л. Эвтаназия (дидактические материалы по биомедицинской этике) URL: http://econf.rae.ru/pdf/2014/11/3806.pdf.

8 Громовчук М.В. Право людини на життя: теоретичні та практичні засади. Порівняльно-аналітичне право. 2017. № 2. С. 38. 
Thus, among many other judgments of the Netherlands Supreme Court, the attention is paid to the decision of 1984, which led to the recognition of voluntary euthanasia at the legislative level. The so-called "Alkmaar case" was about a 95-year-old woman who was terminally ill. A few days before her death, her health deteriorated significantly: she could neither drink nor eat and subsequently, she went faint. Regained consciousness, the woman begged her physician to end her life because she did not want to experience it again. The physician was convinced that day after day, the patient's condition would worsen and decided to act according to the patient's will. The Netherlands Supreme Court pointed out that although the actions of the physician were triggered by "force majeure", which caused a conflict of duties: on the one hand, the physician shall alleviate the patient's hopeless sufferings and, on the other, he has the duty to the law - to save a life. However, the physician had to provide a medical report that made it clear that the person had carefully considered the decision and allowed the patient to die with dignity. The case was taken to court in The Hague where the physician was declared not guilty.

At the same year, the Royal Dutch Medical Association marked that euthanasia might be allowable under certain circumstances. In the statement, it relied on the criteria on which courts had focused when deciding on euthanasia cases. In particular: 1) a patient should request for euthanasia, and the decision must be carefully considered and persistent; 2) a patient feels unbearable suffering (physical or mental), and if recovery is impossible; 3) a physician shall carry out euthanasia after counseling of independent expert, who is experienced in the area concerned.

Within a year (in 1985), the Netherlands State Commission on Euthanasia, which appealed to the Ministry of Welfare, Health and Culture, the Ministry of Justice to amend the Criminal Code on the part of euthanasia and assisted suicide, was established. The Commission proposed to amend the Criminal Code in such a way that deliberate termination of another person's life at his/her request would not be a crime if it is performed by a physician towards a patient who is "in an unfavourable situation without prospects for recuperation”. The physician shall provide recommendations on minors, mentally disabled people, persons with disabilities and prisoners as well as on funeral procedures and death certificate, the non-involvement of others, except patients and physicians, in decision making and the preparation and dispensing drugs prescribed to end up. However, the proposal was not included in the Criminal Code.

Another factor that influenced the introduction of euthanasia at the legislative level in the Netherlands was the medical practice of physicians. After the adoption of court decisions in 1991, the Netherlands State Commission on Euthanasia headed by Prof. J. Remmelink published the international report "End-of-life decisions", which included data concerning not only euthanasia but also other medical decisions that had caused a 
patient's death ${ }^{9}$. The researches were conducted in 1990 by Dr P. van der Maas from Erasmus University Rotterdam. The researches provide the data that euthanasia was applied to 2300 persons that are $1.8 \%$ of the total death rate -129000 persons. It also involves 400 cases - suicides assisted by a physician ( $0.3 \%$ of all deaths). In 22500 cases, patients died due to the discontinuation or refused treatment that caused the end of life. In $40 \%$, the decision on the increase of the drugs doze to hasten the death was previously discussed with a patient, and in $73 \%$ of cases, patients were not able to make that sort of decision.

Therefore, the data provided in the report made it possible to conclude that in most cases of euthanasia, the patient showed the initiative to use it. The rest of the patients were terminally ill but were incapable of making that decision. Therefore, the consent for the euthanasia was provided by close relatives or family members. In most cases, according to the physician, the time hastening the death ranged from several hours to several days.

Another research conducted by G. van der Wald from the Medical Inspectorate of Health was based on private messages from physicians received confidentially. The research was published a year later and confirmed the findings of euthanasia report of the committee. Besides, statistics indicating that in $0.8 \%$ of all deaths, physicians prescribed or administered pharmaceutical drugs to terminate patients' lives without their explicit request drawn attention. In most of these cases, death was inevitable as patients had an end-stage malignant tumour.

In 1990, the Ministry of Justice of the Netherlands and the Royal Dutch Medical Association developed a list of obligatory procedures while exercising euthanasia, which would guarantee immunity from prosecution according to Arts. 293 and 294 of the Criminal Code of the Kingdom of Netherlands. The rules are based on the abovementioned proposals which were developed by the Royal Dutch Medical Association in 1984. Therewith, procedural issues concern the following points: a physician shall conduct euthanasia; before euthanasia, the physician shall consult with an independent expert (physician) who has experience in the area under consideration; the physician shall carry out the full written history of the case; it is necessary to notify the prosecutor's office on death as about euthanasia or physician-assisted suicide but not as about natural cause death.

In the case of notice about death as about a case of euthanasia or physicianassisted suicide, the physician shall complete a form including some questions about the death. Based on the form, it is analyzed the procedure of compliance with all requirements. Subsequently, the procedure of notification was introduced into the Dutch Law "On Burial and Cremation Act”.

${ }^{9}$ Громовчук М.В. Право людини на життя: вибрані аспекти. Visegrad Journal on Human Rights. 2017. № 2/1. S. 59.

96 
Thus, following research and discussion, on 1 June 1994, the amendments to Article 293 of the Criminal Code of the Kingdom of Netherlands came in force, which recognized euthanasia as a crime (but not a homicide) and are contained in Section XIX of the Criminal Code of the Kingdom of Netherlands "Violent crimes against life". Under Article 293 of the Criminal Code, a person who deprived another person of life at his/her express and sincere request shall be imprisoned for a term not exceeding twelve years or set a fine of the fifth category. Then, it is said that a person should not be punished if he/she is a physician and has committed a crime on the grounds of due care following Part 2 of "Termination of Life on Request and Assisted Suicide (Review Procedures) Act" and who has informed the municipal forensic pathologist according to section 7 (2) of "Burial and Cremation Act".

At the same time, the natural evolution of the issue of euthanasia legalization, which took place in several European countries, came to an end on April 2, 2002, when "Termination of Life on Request and Assisted Suicide (Review Procedures) Act” of the Kingdom of Netherlands consolidated the right to assisted suicide and euthanasia. Under the conditions of the act, persons who have reached the age of 16 have the right to manage end-of-life independently. Individuals aged between 12 and 16 need the consent of parents or other legal to carry out this act. The physician conducting euthanasia must be sure that the patient's request is independent, repeated and conscious, and the suffering of the person is long-lasting and unbearable. Moreover, it is obligatory to inform the patient about his condition and prospects for restoration. The decision on euthanasia is taken collectively by consensus, taking into account individual opinions. However, it should be noted that patients from other countries cannot come to the Netherlands for euthanasia it is prohibited by law. The prohibition is substantiated by the fact that there must be a trusting relationship between the physician and the patient ${ }^{10}$.

Therefore, nowadays, euthanasia can only be used in the Netherlands if the following conditions are simultaneously met: 1 ) the patient's suffering is unbearable, and there is no chance for recuperation; 2) the patient's request for euthanasia must be voluntary and cannot be fulfilled within a certain time if the person is under the influence of drugs or other people, has a mental disorder; 3) the patient should be fully aware of his/her condition, prognosis and his/her rights; he/she should be acquainted with at least one independent physician who must confirm the patient's health condition (in practice, two physicians are involved); 4) euthanasia should be medically performed by a physician or a patient in the presence of the physician ${ }^{11}$.

${ }^{10}$ Громовчук М. Евтаназія в зарубіжних країнах: питання конституційно-правового закріплення. Реформування законодавства України та розвиток суспільних відносин взаємодії: Матеріали міжнародної науково-практичної конференції (21-22 квітня 2017 р.). Ужгород. С. 17.

${ }^{11}$ Ibid. C. 18. 
However, the issue of euthanasia runs to the absurd today. Thus, as Minister of Health Edith Schippers and Minister of Security and Justice Art van der Stehr reported in the Dutch media on October 13, 2016, in the Netherlands, the legislators are going to release a draft law according to which not only terminally ill persons but also all who consider "their life is terminated” can obtain permission for euthanasia.

\section{CONCLUSIONS}

Taking into account the provisions specified in the declarations, codes, statements and resolutions that directly relate to and regulate the activities of health workers while exercising their powers (medical practice), the authors can conclude that none of these documents provides provisions for the use of euthanasia as a primary duty of the physician. On the contrary, the medical professionals carry out their activities following the principles "do not to harm", "to reduce suffering", "to help". However, based on the analysis of the medical practice considered in the article, it is clear that the use of euthanasia didn't follow the principles of help. Moreover, all relevant procedures for euthanasia use were not observed, and physicians' decisions were untimely and unjustified. For this very reason, this practice has led to the fact that the number of euthanasia applicants is increasing today, and the medical indicators for its use are leveled off. Not only people who are terminally ill and suffering but also mentally ill people or those who have depression request for euthanasia. Taking into account the above, the authors believe, the countries which are going to introduce euthanasia at the legislative level, first of all, should pay attention to those negative factors that have arisen during its long-term application, in particular, the experience of the Netherlands.

\section{SUMMARY}

Some aspects of the possibility of using euthanasia are covered. The author draws attention to the relation between the categories "euthanasia" and "bioethics". The emphasis has been placed on the legal and medical aspects of the applying of euthanasia, based on the practice of the Netherlands.

\section{REFERENCES}

1. Коваль М.I. Контрміра евтаназії - паліативне лікування. Вісник сочіальної гігієни та організації охорони здоров'я Украӥни. 2015. № 3 (65). C. 54-58.

2. Терешкевич Г. Т. Основи біоетики та біобезпеки : підручник. Тернопіль : ТДМУ, 2014. 400 с.

3. Коротких К. С. Эвтаназия как философско-правовая проблема. Вісник Начіонального університету «Юридична академія України імені Ярослава Мудрого». 2012. № 4 (14). С. 141-149. 
4. URL: https://zakon.rada.gov.ua/laws/show/990_005.

5. URL: Kebuladze B. Termination of Life on Request and Assisted Suicide European Scientific Journal December 2016/SPECIAL/edition. ISSN: 1857 - 7881. (Print) e - ISSN 1857-7431 S. 424 (421-425).

6. Панищев А.Л. Эвтаназия (дидактические материалы по биомедицинской этике) URL: http://econf.rae.ru/pdf/2014/11/3806.pdf.

7. Громовчук М.В. Право людини на життя: теоретичні та практичні засади. Порівняльно-аналітичне право. 2017. № 2. С. 37-41.

8. Громовчук М.В. Право людини на життя: вибрані аспекти. Visegrad Journal on Human Rights. 2017. № 2/1. S. 58-63.

9. Громовчук М. Евтаназія в зарубіжних країнах: питання конституційно-правового закріплення. Реформування законодавства України та розвиток суспільних відносин взаємодії: Матеріали міжнародної науково-практичної конферениї (21-22 квітня 2017 р.). Ужгород. С. 15-21.

Information about the author: Hromovchuk M. V.,

Candidate of Law, Associate Professor at the Department of Constitutional and Comparative Law, Uzhgorod National University 26, Kapitulna str., Uzhgorod, 88000, Ukraine 